\title{
SEKS PRANIKAH DAN PENANGANANNYA PERSFEKTIF BEHAVIOR DAN KONSELING ISLAM
}

\author{
Dwi Widarna Lita Putri ${ }^{1}$ \\ litaputri@uinmataram.ac.id \\ Riska Sanaputri ${ }^{2}$ \\ riskasanaputri@gmail.com
}

\begin{abstract}
ABSTRAK Seks pranikah yang terjadi dikalangan remaja saat ini yang semakin hari semakin memprihatinkan. Tujuan dari penelitian ini ialah untuk mengetahui bagaimana penanganan seks pranikah persfektif behavior dan konseling islam yang dilakukan di Desa Tepas Kecamatan Brang Rea Kabupaten Sumbawa Barat. Metode yang digunakan dalam penelitian ini yaitu penelitian kualitatif deskriptif. Artinya data yang dikumpulkan bukan dari berupa angka-angka melainkan data tersebut berasal dari naskah wawancara, catatan lapangan, dokumen pribadi, catatan memo dan dokumen resmi lainnya. Teknik yang digunakan adalah teknik behavior dan konseling islami. Teknik behavior berupa model assesment fungsional, eksposure terapi, asestion traning, dan self management. Sedangkan teknik konseling islami yang digunakan yaitu pendekatan sepritual dan menjalin kasih sayang. Hasilnya dari beberapa teknik diatas, teknik yang sangat berpengaruh dan bisa membuat para konseli atau korban merasa nyaman dan terelepas dari segala beban ialah teknik konseling islam yang pendekatan secara spritual karena para korban merasa lebih dekat dengan Sang Peciptanya.
\end{abstract}

\section{Keywords: Perilaku, Seks Pranikah, Remaja.}

\section{PENDAHULUAN}

Ditengah gempuran arus informasi asing yang ditularkan melalui media massa yang banyak mengeksploitasi tentang seks, mengakibatkan sedikit banyak perubahan nilai serta norma dalam suatu masyarakat yang sudah tertanam sejak dahulu. Budaya barat yang identik dengan kebebasan yang menyalahi budaya Indonesia, juga sering ditiru oleh masyarakat. Anehnya, masyarakat terlebih para remaja bersikap membolehkan perubahan terjadi pada mereka dan sekitarnya. Bahkan mereka menirunya berulang kali tanpa rasa penyesalan. Pergaulan bebas yang diperlihatkan diluar negeri seperti ciuman bibir menjadi gaya pacaran anak muda zaman sekarang ${ }^{3}$. Berpelukan, apalagi seks merupakan perilaku yang dianggap menyimpang dari norma yang berlaku dimasyarakat di Indonesia, sehingga kaum remaja dalam melakukan perilaku tersebut secara sembunyi.

Seks pra nikah belakangan ini sangat marak dikalangan remaja di Indonesia. Bahkan sangat memprihatinkan karena sudah banyak kasus yang mengakibatkan sampai bunuh diri, dan aborsi karena pelakunya yaitu si pria tidak

1 Penulis merupakan dosen di Universitas Islam Negeri Mataram

2 Penulis merupakan mahasiswa di Universitas Islam Negeri Mataram

3 Mega Ardina, Opini Mahasiswa Terhadap Perilaku Seks Pranikah. Journal Of Health Studies Vol.1 No.2 sept.2017, 149 
mau bertanggung jawab. Namun disamping itu ada yang memang nasibnya baik, dimana laki-lakinya mau bertanggung jawab dan menikahinya walaupun usianya belum matang. Pernikahan di bawah umur banyak terjadi yang mengakibatkan kesehatan reproduksi mereka terganggu. Organ reroduksi masih belum produktif untuk melakukan hubungan seksual, apalagi sampai hamil, yang berdampak buruk bukan hanya untuk wanita, pria juga akan merasa stress dan frustasi jikalau belum bisa bertanggung jawab karena mereka belum mampu melakukan tugas layaknya laki-laki yang sudang matang. Bukan hanya kehamilan yang tidak diinginkan dan aborsi, penyakit menular lainnya seperti sifilis, kencing nanah, dan HIV/AIDS 4 . Selain berdampak negatif bagi remaja, berdampak pula pada bayi yang dilahirkan karena beresiko tertular penyakit dan biasanya terlahir tidak sempurna atau cacat.

Selain berdampak secara fisik, remaja yang menikah diusia yang belum matang pun kadang sangat berpengaruh terhadap psikisnya yaitu para remaja yang nikah muda berujung pertengkaran, perselingkuhan, KDRT, bahkan sampai perceraian. Selain kematangan psikologis dan fisologis atau jasmani, kematangan sosial ekonomi juga sangat berpengaruh, karena pasangan yang menikah diusia yang masih sangat muda secara finansial masih belum bisa mencukupi kebutuhan seharihari. Keduanya masih sangat muda untuk mencari pekerjaan.

Begitu banyak dampak negatif dari seks pranikah namun beberapa remaja terjerat dengan permasalahan tersebut karena rendahnya pendidikan moral dan agama ${ }^{5}$. Seks pranikah yang terjadi kurangnya pemahaman tentang agama, sejalan dengan pelajaran agama di beberapa sekolah mulai dihapus sedikit demi sedikit mengakibatkan para remaja awam akan nilai religiusnya. Kalaupun memang ada pelajaran agama itupun masih belum seimbang antara pengetahuan dengan pengamalan dan pemahamannya. Sebagai orang tua, mereka sangat berperan penting untuk penentuan masa depan anaknya. Pengawasan juga sangat penting, bukan berarti orang tua mengekang anak-anaknya untuk bersosialisasi dengan dunia luar ataupun teman sebayanya karena tidak jarang orang tua dari remaja seks pranikah pun menjadi korban. Orangtua merasa sangat terpukul dan bahkan stress karena beranggapan bahwa mereka tidak bisa mendidik sehingga harus menanggung malu akibat perbuatan anaknya. Namun disisi lain sebagian orang tua untuk menutupi aib dari anaknya tersebut, mereka memutuskan untuk menikahkan anak remajanya padahal kalau menurut agama tidak boleh menikahkan wanita yang hamil terlebih dahulu, kecuali dia telah melahirkan baru bisa dinikahkan walaupun laki-lakinya memang ayah dari bayi yang dikandung. Jika anaknya perempuan maka tidak mahram dengan ayahnya ${ }^{6}$.

Di Desa Tepas dan desa-desa lainnya yang ada di Kecamatan Brang Rea terdapat kasus yang demikian. Sangat disayangkan karena sebagian besar orang tua kurang memahami proses menikahkah anak remajanya yang hamil diluar nikah.

${ }^{4}$ Syamsul Huda B dkk, Faktor Yang Memepengarubi Perilaku Seks Pranikah Mahasiswa Di Pekalongan Tabun 2009-2010, Jurnal Kesehatan Reproduksi Vol.1 No.1 Desember 2010, 36

${ }_{5}^{5}$ Siti Mulidah, DKK. Pola Asub Orang Tua Dengan Sikap Remaja Tentang Seks Pranikah. Jurnal Poltekes Semarang, Vol.11 No. 11 2015, 958

${ }^{6}$ Desa Tepas Kec.Brang Rea Kab.Sumbawa Barat,Observasi 12 agustus 2018 


\section{Qawwãm • Volume 13 Nomor 2, Desember 2019}

Beberapa yang menjadi korban seks pra nikah di Desa Tepas suaminya tidak punya pekerjaan atau bisa dibilang pengangguran. Mereka numpang hidup kepada mertuanya atau orang tua dari istrinya. Padahal untuk menafkahi itu tanggung jawab seorang suami. Selain itu ada yang baru setahun menikah dan anaknya masih kecil, istrinya menjadi TKW ke luar negeri dan suaminya yang diam di rumah mengantikan posisi istrinya. Itu semua dilakukan karena mereka tidak memiliki penghasilan untuk membiayai kehidupan mereka. Berdasarkan pemaparan di atas, peneliti tertarik untuk melakukan penelitian sehingga mengetahui mengapa setiap tahunnya jumlah remaja yang menjadi korban dan pelaku seks pranikah semakin bertambah bahkan sekrang bukan hanya remaja akhir namun remaja awal pun sudah masuk keranah seks pranikah ${ }^{7}$.

\section{METODE}

Kajian dalam penelitian ini merupakan gabungan antara pendekatan empiris dan eksperimen. Penelitian ini menggunakan pendekatan penelitian kualitatif deskriptif. Artinya data yang dikumpulkan bukan berupa angka-angka, melainkan data tersebut berasal dari naskah wawancara, catatan lapangan, dokumen pribadi, catatan memo, dan dokumen resmi lainya. Sehingga yang menjadi tujuan dari penelitian kualitatif ini adalah ingin menggambarkan realita empirik dibalik fenomena secara mendalam, rinci dan tuntas. Oleh karena itu penggunaan pendekatan kualitatif dalam penelitian ini adalah dengan mencocokan antara realita empirik dengan teori yang berlaku dengan menggunakan metode deskriptif.

\section{KAJIAN TEORI}

\section{A. Seks Pranikah}

Seks dalam bahasa Latin adalah sexus, yaitu merujuk pada alat kelamin. Seks hanya memiliki pengertian mengenai jenis kelamin, anatomi dan fisiolagisnya. Sedangkan menurut Budiarjo seksual merupakan sesuatu yang berhubungan dengan seks dan reproduksi juga berhubungan dengan kenikmatan yang berkaitan dengan tindakan reproduksi ${ }^{8}$. Sedangkan menurut Thomburg menjelaskan seksualitas meliputi karakteristik hasil proses belajar psikoseksual (nilai, sikap, dan norma). Seks pra nikah merupakan aktivitas seksual yang dilakukan tanpa mengindahkan nilai-nilai dan norma-norma dalam masyarakat yang mengaturnya. Selain itu relasi seks mereka bersifat tidak tetap atau cendrung tidak setia pada pasangan mereka. Sebagian besar remaja yang terjerumus pada perilaku seks pra nikah merupakan akibat dari stimuli atau rangsangan melalui gambar-gambar porno, sering nonton film porno, dan stimuli melalui lingkungan pergaulan misalnya seorang teman menceritakan pengalaman seksualitasya.

B. Perspektif Behavior

Terapi behavioral berasal dari dua arah konsep yakni Pavlovian dan

${ }^{7}$ Desa Tepas Kec.Brang Rea Kab.Sumbawa Barat,Observasi 12 agustus 2018

8 Dhede," Perilaku Seks Pranikah Pada Remaja"dalam http://www.epsikologi.com \remaja $\backslash 030602 . \mathrm{html}$ 
Skinnerian. Mulanya terapi ini dikembangkan oleh Wolpe untuk menanggulangi treatment neurosis. Neurosis dapat dijelaskan dengan mempelajari perilaku yang tidak adaptif melalui proses belajar. Dengan perkataan lain bahwa perilaku menyimpang bersumber dari belajar atau belajar tertentu. Perilaku dipandang sebagai respons terhadap stimulasi atau rangsangan eksternal atau internal. Dasar teori terapi behavior adalah bahwa perilaku dapat dipahami sebagai hasil kombinasi, belajar waktu lalu dalam hubungannya dengan keadaan serupa, motivasional sekarang dan efeknya terhadap kepekaan lingkungan, serta perbedaan-perbedaan biologik baik secara genetik atau karena gangguan fisiologik ${ }^{9}$.

Perspektif behavioral, pendekatan ini awalnya diperkenalkan oleh John B. Watson. Conditioning and learning memegang peranan yang sangat penting dalam pendekatan behavior, terutama dalam memahami urutan terbentuknya tingkah laku. Pendekatan behavior merupakan usaha untuk memanfaatkan secara sistematis pengetahuan teori dan empiris yang dihasilkan dari penggunaan metode eksperimen dalam psikologiuntuk memahami dan menyembuhkan polo tingkah laku abnormal. Untuk pencegahan dan penyembuhan abnormalitas dimanfaatkan hasil studi eksperimental baik secara deskriptif maupun remedial. Pendekatan behavior bertujuan untuk menghilangkan tingkah laku yang salah dan membentuk tingkah laku baru. Pendekatan tingkah laku dapat digunakan dalam penyembuhan berbagai gangguan tingkah laku dari yang sederhana hingga yang komplek, baik individu maupun kelompok. Teknik-teknik behavior adalah 1) Teknik operan conditioning, prinsip-prinsip dalam behavior adalah penguatan negatif, extinction, hukuman positif, dan hukuman negatif. 2) Model asesmen fungsional, merupakan blueprint bagi konselor dalam memberikan intervensi yang diperlukan oleh konseli. Langkahlangkah yang disiapkan konselor dilakukan tahap demi tahap dalam memberikan perlakuan. 3) Relaxation training and related methods, adalah teknik yang dipakai untuk melatih konseli agar melakukan relaksasi. Dalam pelaksanaannya, konselor dapat memodifikasi teknik ini dengan systematic desentisization, assertion training, self management program. teknik ini biasanya digunakan untuk terapi klinis. 4) Systematic desentisization adalah teknik yang tepat untuk terapi bagi konseli yang mengalami phobia, anorexia nervosa, depresi, obsesif, kompulsif, gangguan body image. 5) Exposure therapies, teknik terapi ini dengan memaksimalkan kecemasan dan ketakutan konseli. 6) Eye movement desentination and reprocessing, didesain dalam membantu konseli yang mengalami post traumatic stress disorder. 7) Assertion training, metode ini didasarkan pada prinsip terapi kognitif perilaku. Ditujukan bagi konseli yang tidak mengungkapkan ketegasan dalam dirinya. 8) Self magement, terapi bagi konseli untuk membantu terlibat dalam mengatur dan mengontrol dirinya ${ }^{10}$.

C. Konseling Islam

Konsep dasar konseling islami yang utamanya berdasarkan Al-Qur'an dan

${ }_{9}^{9}$ Deni Febriani, Bimbingan Konseling, Bengkulu: Teras, 2011, 11

10 Sigit Sanyata, Teori dan Aplikasi Pendekatan Behavioristik dalam Konseling, jurnal paradigm, Nomor 14, Juli 2012, 4 


\section{Qawwãm • Volume 13 Nomor 2, Desember 2019}

Hadis seperti dalam surah Al-Qamar ayat 40. Al-Qur'an dan sunnah Rasul adalah landasan ideal dan konseptual bimbingan konseling islam. Dari kedua dasar tersebut, gagasan, tujuan dan konsep-konsep bimbingan konseling islam bersumber. Segala usaha atau perbuatan yang dilakukan oleh manusia selalu membutuhkan adanya dasar sebagai pijakan untuk melangkah pada suatu tujuan, yakini agar orang tersebut berjalan baik dan terarah. Begitu juga dalam melaksanakan bimbingan Islam didasarkan pada petunjuk Al-Quran dan hadits, baik yang mengenai ajaran memerintah atau memberi isyarat agar memeberi bimbingan dan petunjuk. Menurut Tafsir Tematik cahaya Al-Quran, bahwa Al-Quran merupakan mukjizat Nabi Muhammad SAW yang abadi, yang diturunkan oleh Allah berbagai cahaya dan petunjuk. Di dalamnya trdapat obat bagi jiwa yang sakit karena penyakit hati yang tertutup, sehingga menjadi obat bagi hati, seperti layaknya ramuan obat-obatan bagi kesehatan. Secara garis besar atau secara umum, tujuan bimbingan konseling islam dapat dirumuskan sebagai membantu individu untuk mewujudkan dirinya sebagai manusia seutuhnya agar mencapai kebahagiaan hidup didunia dan diakhirat. ${ }^{11}$

Tujuan dari pelayanan konseling islam yakni untuk meningkatkan dan menumbuh suburkan kesadaran manusia tentang eksistensinya sebagai makhluk dan kholifahnya Allah SWT dimuka bumi ini, sehingga setiap aktivitas dan tingkah lakunya tidak keluar dari tujuan hidupnya yaitu untuk menyembah dan mengabdi kepada Allah SWT.

Teknik konseling islami dimaknai bersumber dari asas ketauhidan yakni a) Latihan spiritual. Dalam hal ini konseli diarahklan untuk mencari ketenangan hati dengan cara mendekatkan diri kepada Allah sebagai sumber ketenangan hati, sumber kekuatan dan penyelsaian masalah serta sumber penyembuhan penyakit mental. b) Menjalin kasih saying. Dimaknai pada asas kerahasiaan, pendekatan kemandirian, dan pendekatan sukarela. Keberhasilan konseling islami juga akan ditentukan oleh terciptanya hubungan baik antara konselor dan konseli. Hubungan yang dimaksud yaitu didasarkan atas kasih sayang. Karena tampa kepercyaan konseli tidak akan tumbuh, sehingga dialog tidak akan berjalan lancer dan sehingga pemberdayaan tidak akan dapat dilakukan. c) Terapi Islam berupa terapi sholat. Shalat merupakan bentuk ibadah fisik yang memiliki banyak kemanfaatan baik sebagai media dalam mendekatkan diri kepada Allah maupun sebagai wahana untuk mendidik individu menjadi muslim yang shaleh bahkan dalam keterangan hadist shalat merupakan ibadah pertama yang dipriksa oleh Allah dihari akhir dan menjadi tolak ukur perbuatan manusia lainnya. Selama manusia memiliki nyawa, kewajiban shalat tidak bisa ditinggalkan.Oleh karena itu, bagi mereka yang sakit tetap memiliki kewajiban untuk melaksanakan shalat sesuai dengan kemampuan yang dimilikinya.Bisa berdiri, duduk, berbaring, atau menggunakan isyarat. Shalat bagi orang yang sakit memberikan kemanfaatan diantaranya, pertama: secara fisik shalat dapat menggerakkan bagian-bagian tubuh sehingga segala persendian dan urat-urat pada tubuh tidak kaku, dan darahpun tidak tersumbat. Kedua, shalat dapat memberikan terapi rasa gundah, galau,dan stres yang menimpa diri manusia. Karena jika

11 Akmun Khairan, Psikologi Konseling, Yogyakarta: Aswaja Pesindo, 2014, 23 
seseorang memilki penyakit psikis maka itu akan berpengaruh terhadap fisik. Ketiga, shalat dapat menghapus dosa, membersihkan jiwa dari noda kesalahan dan menghilangkan perasaan berdosa pada diri seseorang.

\section{PEMBAHASAN}

Pandangan dan penanganan seks pranikah bagi sepuluh remaja perempuan yang melakukan seks pranikah yaitu dengan perspektif behavior dan konseling islami. Dalam perspektif behavior menurut BF. Skinner bahwa perilaku dipandang sebgai respon atau stimulus atau perangsangan eksternal dan internal. Karena itu tujuan terapi adalah untuk memodivikasi metode stimulus respon sebisa mungkin. Dari konseling behavior bahwa perilaku dipahami sebagai hasil kombinasi : 1) belajar waktu lalu dalam hubungannya dengan keadaan serupa, 2) Keadaan motivasional sekarang dan efeknya terhadap kepekaan lingkungan, 3) Perbedaan biologik baik secara genetik maupun karena gangguan fisiologis. ${ }^{12}$ Tujuan konseling behavioral adalah untuk membantuk konseli mebuang respon yang lama yang merusak diri dan mempelajari rsepon yang baru yang lebih sehat.

Merujuk pada teori diatas bahwasannya korban seks pranikah berupaya untuk memperbaiki tingkah laku yang sebelumnya sudah sangat mengkhawatirkan, seperti bersikap sewajarnya dengan keluarga dan masyarakat. Tidak bertingkah tempramental yang bahkan biasa saja kalap jikalau mengingat masa dimana dia terpuruk, tidak mengulang perilaku yang terdahulu yang menjerumuskan dia ke perilaku seks pranikah. Intinya tingkah laku positif yang sejalan dengan fikiran baru yang positif yaitu dengan beberapa cara berupa a) Asesmen. Upaya untuk mengumpulkan data tentang korban seks pranikah, agar peneliti bisa memahami dan mengetahui bagaimana latar belakang dari korban seks pranikah yang berada di Desa Tepas. Assessement disebut juga dengan penilaian ialah suatu penerapan dan penggunaan berbagai cara dan alat untuk mendapatkan serangkaian informasi tentang seks pranikah di Desa Tepas. ${ }^{13}$ Dalam hal ini sebaiknya konselor mempertimbangkan tentang apkah permasalahan konseli telah terungkap atau masih kurang jelas. Apabila informasi telah tercukupi baik informasi yang diperoleh dari konseli sendiri maupun dari pihak lain konselor telah berupaya memahami secara keseluruhan permasalahan yang dialami oleh konseli maka assasement dapat dilakukan. ${ }^{14}$

Assesment behavior merupakan proses pengumpulan dan analisis terhadap data atau informasi tentang konseli atau korban seks pranikah, cara mengukur perilaku korban seks pranikah apakah perilaku yang dimunculkan itu meningkat atau berkurang, dan proses pengumpulan informasi mengenai konseli atau korban seks pranikah untuk mendapatkan pemahaman yang lebih baik mengenai korban. ${ }^{15}$

Dalam assesment behavior mencangkup sejumlah teknik pengukuran yang

12 Sofyan S.Wilis konseling individu teori dan praktek, Bandung: PT .Alfa Beta, 2017,

13 http:/ /www.saranapengetahuan.com

14 Zainul Anwar, Praktik Konseling, Malang: UMM, 2014, 1

15 Psikologi Malang.ac.id 


\section{Qawwãm • Volume 13 Nomor 2, Desember 2019}

berdasarkan pencatatan perilaku korban. Teknik ini digunakan untuk mengidentifikasi perilaku yang bermasalah dan memahami faktor apakah yang mempertahankan munculnya perilaku tersebut serta untuk mengembangkan dan memperbarui intervensi yang tepat untuk mengubah perilaku tersebut. Assesment perilaku mengandal hampir sepenuhnya pencatatan secara eksklusif pada perilaku yang dapat diamati perilaku yang dilakukan korban seks pranikah yang dapat dilihat oleh orang lain. ${ }^{16} \mathrm{Hal}-\mathrm{hal}$ yang digali dalam assesment meliputi analisis tingkah laku bermasalah yang dialami oleh korban saat ini, yaitu analisis situasi yang didalamnya terjadi masalah korban, analisis diri, analisis hubungan sosial, lingkungan, fisik dan budaya. ${ }^{17}$

Merujuk pada teori diatas bahwasannya dalam melakukan assasement data korban seks pranikah yang ada di Desa Tepas, peneliti hanya memerlukan waktu singkat untuk mengumpulkan data permasalahn korban karena sebelumnya peneliti sudah melakukan observasi sebelum penelitian dimulai, disamping itu yang menjadi korban seks pranikah kebanyakan dari orang yang peneliti kenal, jadi tidak terlalu sulit dalam mengasesment. Tujuan melakukan assasement agar peneliti dapat mengetahui latar belakang dan keadaan dari korban seks pranikah.

Cara kedua dalam mewujudkan tingkah laku positif yang sejalan dengan fikiran yaitu dengan pendekatan emosional. Dalam konseling pendekatan emosional dan membangun hubungan yang baik dengan konseli korban seks pranikah sangatlah penting karena sebelum ketahap selnjutnya dan sampai tahap pemecahan masalah, pada tahap ini peneliti harus menunjukkan bahwa peneliti dapat dipercaya dan bisa membantu konseli korban seks pranikah menangani masalahnya. Menurut willis bahwa dalam konseling harus berbentuk working relationship yaitu hubungan yang berfungsi, bermakna, dan berguna. Dalam hal ini peneliti dan korban seks pranikah akan saling terbuka satu sama lain tanpa ada kepura-pura, selain itu peneliti dapat melibatkan korban seks pranikah terus menerus dalam proses konseling. Keberhasilan pada tahap ini dapat menentukan keberhasilan dalam pengambilan keputusan untuk penyelesaian masalah korban seks pranikah. Pada tahapan ini peneliti dapat menciptakan suatu perkenalan yang memungkinkan terbangun kedekatan dan kepercayaan korban, dengan cara menunjukkan perhatian, penerimaan, penghargaan.

Dimana langkah awal yang dilakukan untuk mendekati korban seks pranikah, dengan upaya mendekati secara emosional, sehingga ketika pendekatan secara emosional dapat dilakukan dengan baik maka korban seks pranikah tersebut, dapat dengan mudah untuk menerima, menyakini, terbuka dan menceritakan lebih dalam terkait dengan permasalah yang di alami setelah menjadi korban seks pranikah. Meyakinkan bahwa korban seks pranikah merasa ketakutan dan khawatir akan kerahasiaan permasalahannya sehingga peneliti berupaya untuk melakukan pendekatan secara emosional dengan menjelaskan kerahsiaan itu akan tetap terjaga

16 http:/ / www.kompasina.com

17 Corey Gerald, Teori dan Praktek Konseling dan Psikoterapi. Bandung, Refika Aditama, 2012, 76 
dan menjalin hubungan baik dengan korban agar peneliti bisa diterima oleh korban.

Berdasarkan hasil penelitian peneliti dengan korban seks pranikah dalam pendekatan emosionalnya, peneliti sebelumnya telah mengenal korban dari latar belakangnya jadi sudah begitu tahu dan mengenali korban, dengan demikian dalam mendapatkan informasi peneliti tidak terlalu kesulitan untuk pendekatan terlebih dahulu. beberapa korban seks pranikah dengan mudah nya terbuka karena telah percaya sepenuhnya dengan peneliti.

Cara ketiga dalam mengidentifikasi masalah dan penyebabnya lebih dalam terkait dengan permasalahan korban seks pranikah Identifikasi masalah adalah proses dan hasil pengenalan masalah. Dengan kata lain identifikasi masalah adalah suatu proses penelitian yang dikatakan paling penting diantara proses lain. Masalah penelitian akan menentukan apakah sebuah kegiatan bisa disebut penelitian atau tidak. Masalah penelitian secara umum bisa ditemukan melalui pengamatan lapangan (observasi) dan sebagainya. Beberapa hal yang dijadikan sumber masalah ialah: bacaan atau sumber bacaan dari jurnal, dari pertemuan ilmiah, observasi atau pengamatan,wawancara dan angket, serta pengalaman. ${ }^{18}$ Apabila hubungan konseling telah berjalan dengan baik, selanjutnya mulai mendiskusikan saran-saran spesifik. Hal yang terpenting dalam langkah ini adalah bagaimana keterampilan peneliti dapat mengangkat isi dan masalah yang dihadapi korban. Setelah pendekatan emosional dilakukan dengan baik selanjutnya peneliti melakukan identifikasi masalah, yang dimana identifaksi terkait dengan beberapa permsalahamn dan penyebabnya, serta peneliti berupaya untuk menggali lebih dalam mengenai permasalahan dan penyebabnya. konselor mengidentifikasi masalah konseli adalah apa yang menjadi unsur masalah konseli, bagaimana pola peristiwa masalah itu terjadi beberapa masalah dialami dan bagaimana keterampilan konseli menangani masalahnya. ${ }^{19}$ Cara keempat dalam mengidentifikasi masalah dan penyebabnya lebih dalam terkait penggunaan beberapa terknik behavior yaitu:

A. Model Asesmen fungsional.

Menggunakan intervensi dalam membantu korban seks pranikah belajar tingkah laku yang lebih efektif, korban harus aktif dalam mempelajari dan menerima tingkah laku yang baru, tetapi dalam konteks tidak ditekankan ataupun dipaksa. Assasment diperlukan untuk mengidentifikasi metode atau teknik yang akan dipilih sesuai dengan tingkah laku yang ingin diubah. ${ }^{20}$ Berdasarkan teori diatas sesuai dengan hasil penelitian dari peneliti dilapangan bahwa, dengan telah diberikannya terapi model assasement fungsional kepada korban seks pranikah di Desa Tepas, tingkah laku mereka mulai mengarah kepada yang lebih baik dari sebelumnya. Dimana tingkah laku yang dulu yang negative perlahan berubah kerah yang lebih positif, itu semua tidak lepas dari keinginan konseli sendiri yang ingin berubah.teknik ini diberikan juga sesuai dengan permasalahn dari korban, maka dengan demikian

18 http:/ /www.ppisb.unsyiah.ac.id

19 Zainul Anwar, Praktik Konseling, Malang: UMM, 2014, 5

20 Sulistryarini dan Mohammad Jauhar, Dasar- Dasar Konseling, Jakarta: Prestasi Pustaka,2014, 201 


\section{Qawwãm • Volume 13 Nomor 2, Desember 2019}

teknik ini bisa semaksimal mungkin diterima oleh korban.

\section{B. Eksposure Therapy.}

Terapi eksposure adalah jenis terapi behavior yang pendekatannya dengan cara memaparkan sesuatu yang ditakutkan oleh seseorang yang mengalami fobia, gangguan kecemasan sosial. Terapi eksposur merupakan terapi dengan memaksimalkan kecemasan atau ketakutan konseli korban seks pranikah.Dua varaisi dari terapi ini adalah in vivo dan flooding. Pada tahap ini konseli membanyangkan situasi yang ditakutinya atau yang membangkitkan kecemasannya, tetapi konseli dihadapkan lansung dengan situasi itu. Peneliti dan konseli membuat hirarti kecemasan untuk melihat tingkat kecemasan yang dimiliki konseli. Secara psikologis, terapi eksposure dikembangkan untuk membantu orang atau konseli menghadapi ketakutan mereka. Ketika konseli yang taakut akan seseuatu, atau mereka cendrung menghindari benda atau situasi. Meskipun penghindaran ini dapat membantu mengurangi perasaan takut dalam jangka pendek, namun dalam jangka panjang membuat rasa takut menjadi lebih buruk. Teknik yang digunakan untuk mengekplorasi segala bentuk kecemasan dan ketakutan korban seks pranikah, agar perasaan cemas dan takut bisa hilang dan bisa memahami perilaku mereka yang baru

\section{Asertion Training.}

Merupakan salah satu teknik dalam terapi behavior, menurut willis asertion traning merupakan teknik yang menitikberatkan pada kasus yang mengalami kesuliatan dalam perasaan yang tidak sesuai dalam menyatakannya, dimana asertion traning digunakan untuk membantu konseli dalam hal tidak dapat menyatakan kemarahan atau kejengkelannya, yang mengalami kesulitan berkata tidak, yang sukar menyatakan cinta dan respon positif, serta konseli yang merasakan tidak punya hak untuk menyatakan pendapat dan pikirannya. asertion traning merupakan penerapan tingkah laku dengan sasaran membantu konseli dalam mengembangkan cara-cara berhubungan yang lebih langsung dalam situasi interpersonal. Prosedur latihan yang diberikan kepada konseli untuk melatih perilaku penyesuaian sosial melalui ekspresi diri dari perasaan, sikap, harapan, pendapat, dan haknya. Teknik ini digunakan untuk menyesuaikan pikiran dan tingkah laku korban seks pranikah. Maksudnya agar sejalan antara pikiran yang positif dan perilaku juga mengikuti pikiran. Sesuai dengan pandangan BF Skinner bahwa asertion traning adalah teknik dalam konseling behavior yang menitik beratkan pada kasus yang mengalami kesulitan dalam perasaan yang tidak sesuai dalam penyampaiannya. Di dalam asertion traning konselor berusaha memberikan keberanian terhadap koseli agar mengatasi kesulitan terhadap orang lain. Pelaksanaan teknik ini dilaksaknakan dengan bermain peran. ${ }^{21}$ Misalnya seorang yang emosi dan persaaannya ingin marah dengan sikap temennya namun dia berusaha menutupi itu semua dengan bersikap manis. sesuai dengan teori diatas bahwasannya peneliti menggunakan teori ini agar si korban seks pranikah dapat mensikrongkan atau menyeimbangkan antara pemikiran dengan perilaku, supaya keduanya berjalan imbang tidak berat sebelah, kalau misalkan pikiran nya beda

21 Sofyan S.Wilis konseling individu. Hlm. 72 
dengan tindakan itu akan sangat berbahaya terhadap diri korban. Setelah dilakukannya terapi ini koran seks pranikah menjadi lebih bijaksana dalam bersikap dan menentukan tindakan kedepan.

\section{Self Management.}

Merupakan proses dimana konseli mengarahkan sendiri perubahan tingkah lakunya dengan strategi terepeutik atau beberapa kombinasi strategi. Self Menegement sebagai kontrol diri dari respon tertentu melalui stimulus yang dihasilkan dari respon lain pada konseli yang sama yaitu melalui stimulus yang dibangkitkan oleh diri sendiri. Tujuan dari Self Menegement adalah untuk mengubah perilaku yang lebih adaptif dari konseli. Teknik ini digunakan agar korban seks pranikah bisa mengenali dan memahami dirinya sehingga dia bisa meengatur dan mengotrol perilaku agar mengarah pada hal yang baik. Konsep dasar dari Self Menegement adalah: a) Proses pengubahan tingkah laku dengan salah satu atau lebih strategi melalui pengelolaan tingkah laku internal dan eksternal konseli. b) penerimaan individu terhadap program perubahan perilaku menjadi syarat yang mendasar untuk menumbuhkan motivasi individu. c) partisipasi konseli untuk menjadi agen perubahan menjadi hal yang sangat penting. d) generalisasi dan tetap mempertahankan hasil akhir dengan jalan mendorong individu jauh lebih baik. ${ }^{22}$

Penangan kedua selain menggunakan teknik behavior adalah penanganan seks pranikah dalam perspektif konseling islam. Hakikat bimbingan kinseling islami ialah upaya membantu individu mengembangkan fitrah iman dan atau kembali kembali pada fitrah iman dengan cara memberdayakan fitrah (jasmaini, rohani, nafs, dan iman) mempelajari dan melaksanakan tuntunan Allah dan Rasul-Nya, agar fitrah yang ada pada individu berkembang dan berfungsi dengan baik dan benar. Pada akhirnya diharapkan individu selamat dan memperoleh kebahagiaan yang sejati di dunia dan akhirat. ${ }^{23}$

Merujuk pada konseling islami adapun konsep dasar konseling islami yang utama berdasarkan pada Al-Qur'an dan hadis seperti dalam surah Al-Qamar ayat 40. Merujuk pada ayat diatas bahwa Al-Qur'an dan Sunnah Rosulullah adalah landasan ideal dan konseptual bimbingan dan konseling islam. Dari kedua dasar tersebut bahwa gagasan dan tujuan dan konsep-konsep dan sumber bimbingan konseling islam. Begitu juga dalam melksanakan bimbingan konseling islam didasarkan pada AL-Qur'an dan Hadis baik mengenai ajaran memerintah atau memberi isyarat agar memberi bimbingan dan petunjuk. ${ }^{24}$

Merujuk pada teori diatas bahwasannya konseli (korban sekspra nikah) korban seks pranikah berupaya untuk melupakan dan menghilangkan pengalaman masa lalu terhadap kondisi atau permsalahan yang dihadapinya, mencoba untuk bersosialisasi kembali dengan masyarakat, yang karena kondisi hamil diluar nikah membuat orang-orang disekitarnya menjauh dan tidak mau bersosialisai dengan

22 http:/ /lutfifauzan.wordpress.com

23 Anwar Sutoyo, Bimbingan dan Konseling Islam, Yogyakarta: Pustaka Pelajar, 2017,

${ }^{24}$ Makmun Khairan, Psikologi Konseling, Yogyakarta: Aswaja Pesindo, 2014, $102-$ 


\section{Qawwãm • Volume 13 Nomor 2, Desember 2019}

korban tersebut.Selain itu konseli (korban) berusaha memperbaiki hubungan dengan peciptanya, dengan lebih taat dalam menjankan shalat, mengikuti berbagai kajian yang diadakan oleh masyakat Desa Tepas yaitu 1) Penanganan Seks Pranikah di Desa Tepas Melalui Konseling Islam yang berupa a) Asessment. Upaya untuk mengumpulkan data tentang korban seks pranikah, dikhususkan di Kantor Urusan Agama (KUA) agar peneliti bisa memahami dan mengetahui bagaimana latar belakang dari korban seks pranikah yang berada di Desa Tepas. Menurut pandangan Lubis bahwa assasemet dalam konseling bersifat fleksibel artinya tidak ada baatsan waktuyang kaku bagi konselor dalam melakukan assasement. Dalam hal ini sebaiknya konselor mempertimbangkan tentang apakah permasalahan konseli telah terungkap atau masih kurang jelas. Apabila informasi telah tercukupi baik informasi yang diperoleh dari konseli sendiri maupun dari pihak lain konselor telah berupaya memahami secara keseluruhan permasalahan yang dialami oleh konseli maka assasement dapat dilakukan. ${ }^{25}$ b) Pendekatan secara emosional spritual dengan korban seks pranikah. Dimana langkah awal yang dilakukan untuk mendekati korban seks pranikah, dengan upaya mendekati secara emosional spritual, sehingga ketika pendekatan secara emosional yang mengarah pada segi spritual dapat dilakukan dengan baik maka korban seks pranikah tersebut, dapat dengan mudah untuk menerima, menyakini, terbuka dan menceritakan lebih dalam terkait dengan permasalahan yang di alami setelah menjadi korban seks pranikah. c). Mengidentifikasi masalah dan penyebabnya lebih dalam terkait dengan permasalahan korban seks pranikah. Setelah pendekatan emosional dilakukan dengan baik selanjutnya peneliti melakukan identifikasi masalah, yang dimana identifaksi terkait dengan beberapa permsalahan dan penyebabnya, serta peneliti berupaya untuk menggali lebih dalam mengenai permasalahan dan penyebabnya. Jiwa manusia dibagi menjadi 3 yaitu pertama jiwa yang cendrung kepada keburukan karena dikuasai oleh hawa nafsu dan duniawi. Kedua Jiwa yang mnyesali diri yakni menyesali kesalahan yang diperbuat tetapi masih mudah tergoda dengan dunia. Ketiga jiwa yang tenang sehingga mencapai kematangan syukur dan sabar. d) Teknik Konseling islami. Teknik konseling islami yang digunakan yaitu pertama pendekatan spiritual dan kedua menjalin kasih sayang. Pendekatan spiritual adalah pendekatan yang dilakukan oleh korban seks pranikah dengan Tuhannya, untuk bertaubat dan menyesali perbuatan yang dilakukan sebelumnya memang salah dan untuk memperbaiki hubungan tersebut. Landasan spritual dalam konseling islam ditekankan pada 3 hal pokok yaitu: ${ }^{26}$ pertama, manusia sebagai makhluk tuhan. Kedua, sikap yang mendorong perkembangan dari kehidupan manusia berjalan kearah yang sesuai dengan kaidah agama. Ketiga, upaya yang memungkinkan berkembang dan dimanfaatkannya secara optimal suasana dan prangkat budaya (ilmu pengetahuan dan teknologi) serta kemasyarakatan yang sesuai dengan meneguhkan kehidupan beragama untuk membantu perkembangan dan pemecahan masalah Teknik ini untuk mengarahkan korban seks pranikah dalam mencari ketenangan hati serta lebih mendekatkan diri kepada Allah SWT, menjadi kekuatan

25 Zainul Anwar, Praktik Konseling, Malang: UMM, 2014, 1

${ }^{26}$ Makmun Khairan, Psikologi Konseling, 98-99 
dan penyelsaian atas segala masalahnya.Manusia diciptakan dengan tujuan yang mulia yakni beribadah kepada Allah. Teknik konseling islami yang kedua yaitu menjalin kasih sayang. Digunakan sebagai upaya agak korban seks pranikah merasa tidak dijauhi karena permasalahannya sehingga merasa disupport sehingga hubungannya dengan orang lain terjalin dengan baik. e) Perencanaan solusi yang diambil. Alternatif solusi yang peneliti tawarkan untuk penyesaian masalah korban seks pranikah ialah harus disesuaikan dengan keadaan, keinginan dan harapan dari korban sehingga solusi yang diambil bisa dijalankan dengan baik serta bermanfaat bagi kehidupannya kedepan.Karena dialah yang lebih mengetahui keadaan dirinya sendiri. Konseling islami meliki tujuan yang mengarahkan individu kepada ketenangan, kebahagiaan, dan keridhaan Allah SW'T.

Konseling islami tidak hanya menyelesaikan masalah yang dihadapi individu tetapi juga mengarhkan individu kembali kepada fitrahnya, dan sistem konseling islam dimulai dari mengarhkan pada kesadaran nurani dan membaca ayatayat Allah, baik yang termuat dalam Al-Qur'an maupun ayat-ayat Allah dalam alam ini. ${ }^{27}$ jika seseorang sudah mendekatkan diri kepada Allah maka kesempatan mereka untuk mendekatkan diri pada kemaksiatan tidak ada karena mereka telah terjaga, terlindungi dan iman mereka kuat untuk melawan segala bentuk godaan syaitan yang akan menjerumuskan mereka kepada hal-hal yang negative yang akan mendatangkan dosa

Dari beberapa treatment yang telah dilakukan oleh peneliti kepada para korban seks pranikah menghasilkan para korban seks pranikah lebih dewasa dalam menyikapi permasalahannya, tidak terlalu terpuruk akan keadaan yang telah menimpanya dan ada semangat baru untuk menata kehidupannya kedepan. Dari segi tingkah laku korban sudah mulai memperbaiki dan mensingkronkan antara perilaku dan pikirannya, dari segi agama mereka sudah lebih mendekatkan diri kepada Allah SWT serta bertaubat dan menyesali perbuatan salah yang telah mereka lakukan.

\section{KEIMPULAN}

Berdasarkan penelitian yang dilakukan peneliti di Desa Tepas mengenai “ Seks Pranikah dan Penangananya persfektif Behavior dan Konseling Islam” peneliti menghasilkan kesimpulan bahwa teknik behavior yang dilakukan yaitu teknik model assesment fungsional, eksposure terapi, asertion traning, dan self management. Sedangkan teknik Konseling Islam yang dilakukan berupa pendekatan spritual, dan menjalin kasih sayang. Dari beberapa teknik tersebut teknik yang sangat berpengaruh dan bisa membuat mereka para konseli atau korban merasa nyaman dan terlepas dari segala beban ialah teknik konseling islam yang pendekatan secara spritual karena para korban merasa lebih mendekatkan diri pada sang peciptanya sehingga para korban merasa lebih nyaman.

\section{DAFTAR PUSTAKA}

Ardina, Mega, Opini Mahasiswa Terhadap Perilaku Seks Pranikah. Journal of Health

${ }^{27}$ Makmun Khairan, Psikologi Konseling, 112 


\section{Qawwãm • Volume 13 Nomor 2, Desember 2019}

Studies Vol.1 No.2. 2017

Basit Abdul, Konseling Islam (Depok: Kencana, 2017)

Corey, G. Theory and Praktice of Counseling and Psychotheraphy (Seventh Edition. Belmont : Brooks $\backslash$ Cole-Thomson Learning, 2005)

Dhed, Perilaku Seks Pranikah pada Remaja. Google http:// www.e-psikologi.com \remaja \030602.html. 2002

Febrini, Deni, Bimbingan Konseling (Yogyakarta: Penerbit Teras, 2011)

Faqih, Ainur Rahim, Bimbingan dan Konseling dalam Islam (Yogyakarta: UII Press, 2001)

Hastutik, Hubungan Pengetahuan tentang Kesehatan Reproduksi dengan Perilaku Seks Bebas (FK Kesehatan Masayarakat ; Yogyakarta)

Huda B, Samsul dkk, Faktor Yang Memepengaruhi Perilaku Seks Pranikah Mahasiswa Di Pekalongan Tahun 2009-2010, Jurnal Kesehatan Reproduksi Vol.1 No.1 2010

Lexy, J Moleong, Metodologi Penelitian Kualitatif (Bandung: PT Remaja Rosdakarya, 2013)

Khairani Makmud, Psikologi Konseling, (Yogyakarta: Aswaja Presundo, 2014)

McLeod, John, Pengantar Konseling Teori \& Study Kasus (Prenadamedia Group, 2010)

Mulidah, Siti dkk. Pola Asuh Orang Tua Dengan Sikap Remaja Tentang Seks Pranikah, Jurnal Poltekes Semarang, Vol.11 No. 11. 2015.

Musari, Bimbingan Konseling Islam (Mataram: Lembaga Pengkajian Publikasi Islam \& Masyarakat IAIN Mataram, 2016)

Rosjidan, Pengantar Teori-teori Konseling. (Jakarta: Departemen Pendidikan dan Kebudayaan, 1985)

Sarlito, W. Sarwono, Psikologi Remaja (Jakarta: PT RajaGrafido Persada, 2013)

Jonatan, Sarwono, Metode Penelitian Kuantitatif dan Kualitatif (Yogyakarta: Graha Ilmu, 2006)

Sulistryarin dan Jauhar Mohammad, Dasar-Dasar Konseling (Jakarta: Prestasi Pustakarya, 2014)

Sofyan, S. Willis, Konseling Individual Teori dan Praktek (Bandung: Alfabeta, 2014) 